\title{
Stock Market Optimism and Cointegration among Stocks: The Case of the Prague Stock Exchange ${ }^{\#}$
}

\section{Jaromír Baxa*}

Only five years ago the Prague Stock Exchange (PSE) was one of many forgotten stock markets in the Central and Eastern European countries with very low trading volumes, just a few stocks on the main market, no initial public offerings (IPO's) and its index PX-50 was gradually depreciating. The effects of market optimism in the late nineties in Warsaw and Hungary and all developed markets didn't spread to Prague and also the fall in 2001 was neither as sharp as in the U.S. nor on other emerging markets.

But since 2002 the situation changed and during last years the PSE noted incredible increase in both trading volumes and prices of traded stocks. The PX index (former PX50) reached the level of 1600 points at the end of 2006, which is almost four times higher than in 2001. The growth was most significant since beginning of 2004 till the first quarter 2006, some traded stocks more than tripled their initial values and the growth was also boosted with several new IPO's. The growth has been more or less common to all securities although there were several minor exceptions and also the stocks of commercial banks rose sharply about one year before the whole market (Graph 1, prices of stocks in Czech koruna, CZK depicted).

Cointegration analysis can show us if the growth has been driven by some hidden common factor(-s) or if the main forces have been in case of each stock individual and specific and the fact, that the increase was similar among many of stocks is only due to coincidence. We have found that the results differ substantially upon the choice of frequency of the data. The interrelations are very small when using daily data, on the other hand weekly data lead to opposite result. Furthermore the analysis of daily data implies that the relations became closer in the long term and that they are almost negligible during the period of high growth (2005-2006), but again the weekly data showed the opposite. Our results showed that using weekly data we can describe the development during this shorter period only with a very small number of common stochastic trends.

The text is organized as follows: first the consequences of cointegration among stocks are described and also the issue of possible inefficiency is touched. The next section is devoted to the results of the cointegration analysis at the PSE and finally the difference between the results with daily and weekly data is discussed. Summary of most important conclusions closes this text.

The support from the Czech Science Foundation under the Grant 402/03/H057 is gratefully acknowledged. PhDr. Jaromír Baxa - student of doctoral study; Institute of Economic Studies, Faculty of Social Sciences, Charles University in Prague, Smetanovo nábřeží 6, 11101 Prague 1, Czech Republic; <jaromir.baxa@centrum.cz>. 
Figure 1: Stock Prices at the Prague Stock Exchange (Prices in CZK) 2001-2006

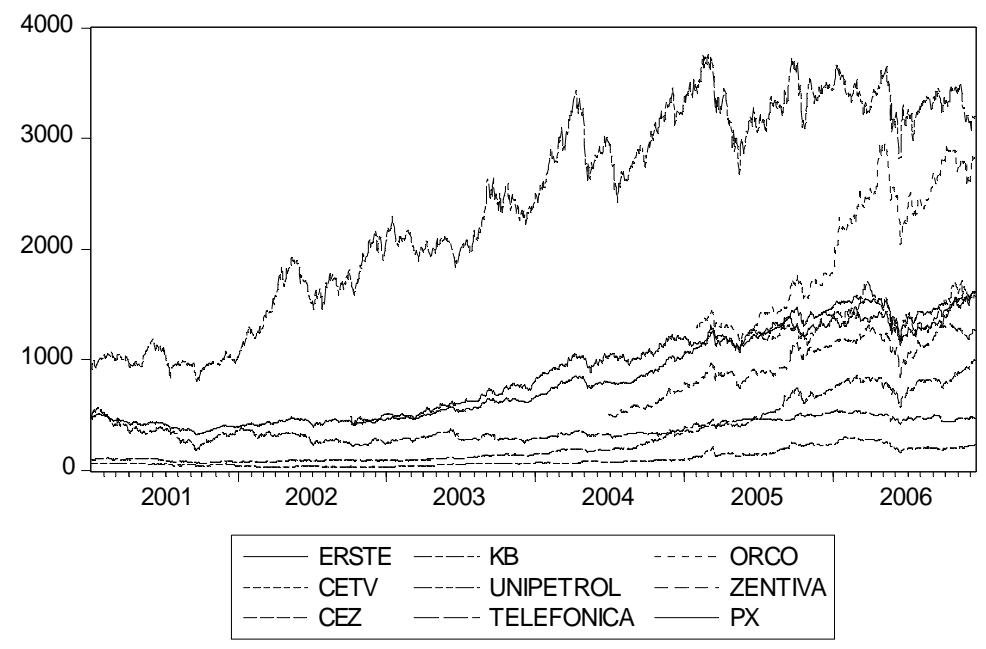

\section{Cointegration among Stocks and its Consequences}

Traditionally correlation coefficients are used as the main analytical tool for describing the relations among group of stocks. However under certain conditions using cointegration instead of correlation may have important advantages, because cointegration allows us to find and identify possible common trends, if they exist. Let's start with the following definition:

Definition: An $(\mathrm{n} \times 1)$ vector time series $\mathrm{x}_{\mathrm{t}}$ is said to be cointegrated if each of the series taken individually is $\mathrm{I}(1)$, that is, nonstationary with a unit root or integrated of order 1, while some linear combination $\beta^{\prime} \mathrm{x}_{\mathrm{t}}$ is stationary, or $\mathrm{I}(0)$, for some non-zero $(\mathrm{n} \times 1)$ vector $\beta .^{1}$ (Hamilton, 2004, p. 571)

As follows from the definition, the notion of cointegration is much stronger than pure correlation, because - loosely saying - if we find cointegration in a group of variables (stock prices in this case), then those cannot wander off in opposite directions for a long-term without coming ,back“ to some long-term equilibrium. Such interpretation follows directly from the error-correction representation of cointegrated systems, which will be illustrated further.

Formally the situation for more than one variable can be stated as follows. Suppose that we have $n \mathrm{I}(1)$ time series $x_{i, t}$ (natural logarithms are assumed), whose long-term relationships can be described using equation (1). If all time series are cointegrated, then by definition all residuals $\varepsilon_{i}$ would be stationary.

$$
\begin{aligned}
& x_{1, t}=c_{1}+\xi_{1,2} x_{2, t}+\xi_{1,3} x_{3, t}+\ldots+\xi_{1, n} x_{n, t}+\varepsilon_{1, t} \\
& x_{2, t}=c_{2}+\xi_{2,1} x_{1, t}+\xi_{2,3} x_{3, t}+\ldots+\xi_{2, n} x_{n, t}+\varepsilon_{2, t} \\
& \ldots \\
& x_{n, t}=c_{n}+\xi_{n, 1} x_{1, t}+\xi_{n, 2} x_{2, t}+\ldots+\xi_{n, n-1} x_{n-1, t}+\varepsilon_{n, t}
\end{aligned}
$$

\footnotetext{
1 A vector satisfying this condition is the cointegrating vector.
} 
However estimating coefficients of such equations would, in case of I(1) variables, lead to "superconsistent“" results (See for example Enders, 2003, for details), so the vector error-correction model (VECM) as a representation of cointegrated systems (2) was found as more appropriate for such analyses of sets of I(1) variables.

$$
\begin{aligned}
& \Delta x_{1, t}=\alpha_{1}+\sum_{k=1}^{K} \delta_{1, k} e_{k, t-1}+\sum_{i=1}^{p} \gamma_{1 \mathrm{i}}^{1} \Delta x_{1, t-i}+\sum_{i=1}^{p} \gamma_{2 \mathrm{i}}^{1} \Delta x_{2, t-i}+\ldots+\sum_{i=1}^{p} \gamma_{n i}^{1} \Delta x_{n, t-i}+\varepsilon_{1, t} \\
& \Delta x_{2, t}=\alpha_{2}+\sum_{k=1}^{K} \delta_{2, k} e_{k, t-1}+\sum_{i=1}^{p} \gamma_{1 \mathrm{i}}^{2} \Delta x_{1, t-i}+\sum_{i=1}^{p} \gamma_{2 \mathrm{i}}^{2} \Delta x_{2, t-i}+\ldots+\sum_{i=1}^{p} \gamma_{n i}^{2} \Delta x_{n, t-i}+\varepsilon_{2, t} \\
& \ldots \\
& \Delta x_{n, t}=\alpha_{n}+\sum_{k=1}^{K} \delta_{n, k} e_{k, t-1}+\sum_{i=1}^{p} \gamma_{1 \mathrm{i}}^{n} \Delta x_{1, t-i}+\sum_{i=1}^{p} \gamma_{2 \mathrm{i}}^{n} \Delta x_{2, t-i}+\ldots+\sum_{i=1}^{p} \gamma_{n i}^{n} \Delta x_{n, t-i}+\varepsilon_{n, t}
\end{aligned}
$$

Here the error-correction terms $e_{k, t-1}$ are estimated residuals from the equations (1).

If there is no cointegration between any pair of time series, then the residuals are not stationary and their interpretation as error correction is also misleading. Thus better job can be done using simpler vector autoregression model (VAR) applied to first differences (3).

$$
\begin{aligned}
& \Delta x_{1, t}=\alpha_{1}+\sum_{i=1}^{p} \gamma_{1 \mathrm{i}}^{1} \Delta x_{1, t-i}+\sum_{i=1}^{p} \gamma_{2 \mathrm{i}}^{1} \Delta x_{2, t-i}+\ldots+\sum_{i=1}^{p} \gamma_{n i}^{1} \Delta x_{n, t-i}+\varepsilon_{1, t} \\
& \Delta x_{2, t}=\alpha_{2}+\sum_{i=1}^{p} \gamma_{1 \mathrm{i}}^{2} \Delta x_{1, t-i}+\sum_{i=1}^{p} \gamma_{2 \mathrm{i}}^{2} \Delta x_{2, t-i}+\ldots+\sum_{i=1}^{p} \gamma_{n i}^{2} \Delta x_{n, t-i}+\varepsilon_{2, t} \\
& \ldots \\
& \Delta x_{n, t}=\alpha_{n}+\sum_{i=1}^{p} \gamma_{1 \mathrm{i}}^{n} \Delta x_{1, t-i}+\sum_{i=1}^{p} \gamma_{2 \mathrm{i}}^{n} \Delta x_{2, t-i}+\ldots+\sum_{i=1}^{p} \gamma_{n i}^{n} \Delta x_{n, t-i}+\varepsilon_{n, t}
\end{aligned}
$$

The only difference between (2) and (3) is that the second term of the right side in (2) is not included in (3) anymore, however if the cointegration exists, omitting those terms would lead to misspecification error.

In order to identify the cointegration among stocks we used the Johansen's methodology. Assume that the set of I(1) variables $x_{t}$ can be described as VAR(p) process (4).

$$
x_{t}=A_{1} x_{t-1}+A_{2} x_{t-2}+\ldots+A_{p} x_{t-p}+\varepsilon_{t}
$$

Such VAR(p) model we can rewrite in terms of VECM (For details see for example Engle-Granger, 1987 or Hamilton, 1994, p. 549):

$$
\Delta x_{t}=\Pi x_{t-1}+\sum_{i=1}^{p-1} \Gamma_{i} \Delta x_{t-1}+\varepsilon_{t}
$$

where $\Pi=\sum_{i=1}^{p} A_{i}-I$ and $\Gamma_{i}=-\sum_{j=i+1}^{p} A_{j}$.

Granger representation theorem states that if the coefficients matrix $\Pi$ has reduced rank $r<n$, then there exist $n \times r$ matrices $\alpha$ and $\beta$ with ranks $r$ such that $\Pi=\alpha \beta^{\prime}$ and $\beta^{\prime} x_{t}$ is $\mathrm{I}(0)$. The number $r$ is the number of cointegrating relations in the model (the so 
called cointegration rank) and the matrix $\beta$ is a matrix of cointegrating vectors. If $\operatorname{rank}(\Pi)=0$, then the matrix is null and the VECM relation is identical to the $\operatorname{VAR}(\mathrm{p})$ process in first differences. On contrary if $\operatorname{rank}(\Pi)=n$, then the vector process is stationary and in all other cases there are $r$ cointegrating relations.

Johansen's method (used in this paper) to identify the existence and structure of cointegrating relations is based on the idea to test how many eigenvalues has the matrix $\Pi$ (as the number of eigenvalues corresponds to the rank of matrix). Two tests are used and computed simultaneously and their results should be in an ideal case consistent with each other: the trace test and the $\lambda_{\text {max }}$ test.

The trace test tests the zero hypothesis of $r$ cointegrating relations, thus that $n-r$ eigenvalues are zero against the hypothesis of $n$ eigenvalues.

$$
\lambda_{\text {trace }}(r)=-T \sum_{i=r+1}^{n} \ln \left(1-\hat{\lambda}_{i}\right)
$$

Here $\hat{\lambda}$ represents the estimated values of the eigenvalues obtained from the estimated $\Pi$ matrix and $T$ is the number of observations. Obviously if $\operatorname{rank}(\Pi)=0$, then there are no cointegrating relations and all eigenvalues would equal to zero and thus also the $\lambda_{\text {trace }}=0$.

The $\lambda_{\max }$ test tests the null of $r$ cointegrating relations against the alternative of $r+1$.

$$
\lambda_{\max }(r, r+1)=-T \ln \left(1-\hat{\lambda}_{r+1}\right)
$$

Critical values for those tests do not follow the $\chi^{2}$ distribution and they were obtained using the Monte Carlo simulations and they are directly incorporated in EViews or other econometric software packages ${ }^{2}$.

\footnotetext{
Technical note: As original time series may contain intercepts and different deterministic trends, the same then holds also for the cointegration equations and this causes that tests statistics (6) and (7) do not have the usual $\chi^{2}$ distribution, but they would depend on the trend specification. Johansen (1995, p. 80) originally assumes five deterministic trend cases such as cointegration equations with zero mean (1.), with a constant term in cointegrating relations (2.), with linear trends, that can be eliminated by the cointegrating relations $\beta$ (3.), or a situation with $r$ trend stationary variables and $p-r$ variables composed from $\mathrm{I}(1)$ variables leading to a situation with a linear trend in a cointegrating relation (4.) and finally quadratic deterministic trend in data and linear trend in cointegrating equation (5.). Formally those situations are specified as follows:
}

1. No deterministic trends in original series $x_{t}$ and the cointegrating equations do not have intercepts.

$\Pi x_{t-1}=\alpha \beta^{\prime} x_{t-1}$

2. No deterministic trends in original series $x_{t}$ and the cointegrating equations have intercepts.

$$
\Pi x_{t-1}=\alpha\left(\beta^{\prime} x_{t-1}+\rho_{0}\right)
$$

3. The original series $x_{t}$ have linear deterministic trends and the cointegrating equations have intercepts.

$$
\Pi x_{t-1}=\alpha\left(\beta^{\prime} x_{t-1}+\rho_{0}\right)+\alpha \perp \gamma_{0}
$$

4. Both original series $x_{t}$ and cointegrating equations have linear deterministic trends.

$$
\Pi x_{t-1}=\alpha\left(\beta^{\prime} x_{t-1}+\rho_{0}+\rho_{1} t\right)+\alpha \perp \gamma_{0}
$$

5. The original series $x_{t}$ have quadratic deterministic trends, the cointegrating equations have linear trend.

$$
\Pi x_{t-1}=\alpha\left(\beta^{\prime} x_{t-1}+\rho_{0}+\rho_{1} t\right)+\alpha \perp\left(\gamma_{0}+\gamma_{1} t\right)
$$

Here the $\Pi$ is the matrix of coefficients from the equation (5) and $\alpha \perp$ is an orthogonal projection of exogenous terms of deterministic trends onto the $\alpha$ space. Thus the terms connected with $\alpha \perp$ are the deterministic terms which are not included in cointegrating relations. For the detailed discussion see Johansen (1995, p. 80-84). As Johansen (1995) showed the presence of deterministic parts in both parts of cointegrating relations leads to not unique identification. Software package, which has been used for estimation (EViews 5.1), uses for identification additional condition of zero mean of error correction term. Various information criteria were used to choose appropriate form of trend specification. As far as lag-length concerns likelihood ratio test (sequential 
As far as economic interpretation of cointegration among stocks on one market concerns above all presence of cointegration has important issues for portfolio management as the possibilities for portfolio diversification are limited, because those stocks move together. Of course cointegration among all stocks may occur more probably in markets with only few stocks included on the main market. And exactly this is the case of the PSE currently there are only 11, in 2005 were 9 and in 2001 only 5 (excluding those, who left the main market, usually after privatization as a result of new owner's strategy). Then it can easily happen that investors evaluate the whole market as successful and with good prospect for further positive returns and growth and consequently prices of all stocks increase. Furthermore fluctuations of prices are caused more by prevailing optimistic or pessimistic perception of the whole region than with individual fundamental factors.

The alternative (and parallel) explanation of possible cointegration among stocks on one market in some period of time (here we deal with years, it is hard to imagine, that stocks of companies from different sectors can be cointegrated for a decade) is based on presumption that particular companies can have very similar fundamental factors as ratios, profit margin, positive expectations about future returns etc. In case of PSE we can say that most companies with stocks on the main market (a) were under-valuated in 20012002 in comparison with similar companies in the EU, (b) their profits were fast growing during this period and (c) their future returns are expected to be increasing as they operate in growing fields and they are expanding through acquisitions. Thus those ,hard“ financial data can play more important role than the differences in branches. Of course there are a few exceptions: the company Philip Morris (producer of cigarettes) seems to be without possibilities for future growth and development of price of their stocks reflects such situation. Similar arguments holds partly also for Komercni banka (commercial bank owned by the Societé General) and Telefonica O2 CZ (telecommunications), because those company did not announced any expansion abroad and prospects for their future growth only in the Czech Republic are limited in comparison with other companies on the main market. Also those stocks didn't increase so much recently, however Komercni banka tripled its market value just between 2002 and 2004.

Based on Granger's classic argumentation (Granger, 1986) cointegration among stocks and stock markets is often connected with the issue of possible inefficiency of the market. According to his argumentation asset prices determined in efficient markets cannot be cointegrated, because in case of cointegration the price movement of one asset will contain information about the other. And so it can be possible to beat the market trading on various markets and exploiting movements in one price to predict the change of the other one. Moosa (1999) states, that the basis of argumentation favoring the interconnection between cointegration and inefficiency stresses that there is a contradiction between two assertions: first prices are not predictable on efficient markets and second deviation of prices from the cointegrating relationship implies predictable future price change. This means that the disequilibrium error can forecasts next period's price change and therefore it is a violation of weak-form efficiency, which stresses that technical analysis cannot lead successful predictions.

Moosa continues describing cases in which the asset prices may be cointegrated although the market efficiency is not violated. First previous arguments holds only for different assets and this is unfortunately too vague definition - if as in our case some 
group of stocks has several important common features like undervaluation, good perspectives and the - differences are only in sectors and if additionally there is a great money inflow on the market as such, then cointegration doesn't inevitably imply inefficiency (Moosa originally uses this argument with prices of heating oil and unleaded gasoline). Second efficient market means that there are no arbitrage opportunities so cointegration among stocks shouldn't be inconsistent with efficiency. Although both arguments are very persuasive and can be easily applied to our problem we don't think that the efficient market hypothesis as summarized by Fama (1970) is consistent with predictability as such and no matter if the stocks are cointegrated or not. And also there are other perhaps more interesting aspects of cointegration among stocks than the discussion about efficiency. Cointegration can show how strong is the influence from one share to another and how those interrelations change in time - if they became stronger or weaker in a long term or short term, if they are stronger in times of market optimism or for example if it helps to identify which prices move together and which do not and use these results for analysis of fundamentals, as cointegration is much stronger relationship than simple correlation.

\section{Cointegration Analysis of the Prague Stock Market 2001-2006}

Until now many papers were written about cointegration and Granger causality among a group of stock markets, very often with respect to the joint-efficiency issue or with the aim to study the market integration. As far as Central European stock markets concerns Syllignakis, M. N. and Kouretas, G. P. (2006) found substantial integration between the Czech, Polish, Slovak, Hungarian and Slovenian stock markets together with the German and the U.S., they also found that integration higher in times of Asian and Russian crisis in the late nineties. On the other hand Egert, B. and Kočenda, E. (2005) found that using 5 minutes frequency of data from 2003-2005 there is no robust cointegration between western and Central European stock markets and Granger causality is bidirectional. Žikeš (2003) tested cointegration between the Czech, German, Hungarian and Polish stock markets and he found that cointegration exists in this group for prices in national currencies only. Analysis about the cointegration among stocks on one market are rare and almost do not exist for the Central European stock exchanges.

We used daily and weekly closing prices of stocks traded on the main market of the Prague Stock Exchange since the 1st January 2001 till the 12th December 2006. The analysis was performed using natural logarithms of those prices. Until 2002 we have only 5 stocks (ČEZ, KB, Philip Morris, Telefonica O2 and Unipetrol, since October 20026 ones (Erste Bank) and the last three stocks were initially offered during 2004 (Zentiva - June 2004) and the first half of 2005 (ORCO and CETV). All time series are I(1) at all samples, which was tested using both Augmented Dickey-Fuller and PhillipsPerron tests. We decided to include also the index PX (former PX-50, but the new index was constructed in the same way as the former one thus both time series are fully comparable) into analysis although actually it is only a linear combination of the others. We had two reasons for that: first its inclusion gives better results and second also the values of the index are known to the investors and the difference between the growth rates of stock and index is often taken into account when deciding about investments. 
Initial information about the comovements of stock prices can be easily obtained from matrices of correlation coefficients - the matrix of pairwise correlation coefficients with daily data can be found in Table 1a and $1 \mathrm{~b}$. For the $1 \mathrm{~b}$ table only the period from June 2005 till December 2006 is considered. The implication of those two tables is clear - the correlation coefficients are generally smaller in shorter period than in the whole sample. Using weekly data we obtained very similar results. As everywhere natural logarithms were used.

Table 1a: Pairwise correlation matrix (2001-2006)

\begin{tabular}{|c|c|c|c|c|c|c|c|c|c|c|}
\hline & CETV & CEZ & ERSTE & KB & MORR & ORCO & PX & TEL & UNIP & ZENT \\
\hline CETV & 1,00 & 0,76 & 0,75 & 0,21 & $-0,37$ & 0,75 & 0,79 & 0,20 & 0,46 & 0,80 \\
\hline CEZ & 0,76 & 1,00 & 0,93 & 0,81 & 0,61 & 0,90 & 0,99 & 0,80 & 0,97 & 0,98 \\
\hline ERSTE & 0,75 & $\mathbf{0 , 9 3}$ & 1,00 & 0,95 & 0,47 & 0,70 & 0,97 & 0,86 & 0,92 & 0,90 \\
\hline KB & 0,21 & 0,81 & $\mathbf{0 , 9 5}$ & 1,00 & 0,90 & 0,18 & 0,88 & 0,45 & 0,71 & 0,69 \\
\hline MORR & $-0,37$ & 0,61 & 0,47 & $\mathbf{0 , 9 0}$ & 1,00 & $-0,74$ & 0,71 & 0,26 & 0,53 & $-0,29$ \\
\hline ORCO & 0,75 & $\mathbf{0 , 9 0}$ & 0,70 & 0,18 & $-0,74$ & 1,00 & 0,84 & 0,43 & 0,67 & 0,90 \\
\hline PX & 0,79 & $\mathbf{0 , 9 9}$ & $\mathbf{0 , 9 7}$ & $\mathbf{0 , 8 8}$ & 0,71 & 0,84 & 1,00 & 0,77 & 0,95 & 0,98 \\
\hline TEL & 0,20 & 0,80 & $\mathbf{0 , 8 6}$ & 0,45 & 0,26 & 0,43 & 0,77 & 1,00 & 0,84 & 0,91 \\
\hline UNIP & 0,46 & $\mathbf{0 , 9 7}$ & $\mathbf{0 , 9 2}$ & 0,71 & 0,53 & 0,67 & $\mathbf{0 , 9 5}$ & 0,84 & 1,00 & 0,94 \\
\hline ZENT & 0,80 & $\mathbf{0 , 9 8}$ & $\mathbf{0 , 9 0}$ & 0,69 & $-0,29$ & $\mathbf{0 , 9 0}$ & $\mathbf{0 , 9 8}$ & $\mathbf{0 , 9 1}$ & $\mathbf{0 , 9 4}$ & 1,00 \\
\hline
\end{tabular}

Table 1b: Pairwise Correlation Coefficients Matrix (6/27/2005-12/12/2006)

\begin{tabular}{|c|c|c|c|c|c|c|c|c|c|c|}
\hline & CETV & CEZ & ERSTE & KB & MORR & ORCO & PX & TEL & UNIP & ZENT \\
\hline CETV & 1,00 & 0,76 & 0,75 & 0,19 & $-0,37$ & 0,75 & 0,79 & 0,20 & 0,46 & 0,80 \\
\hline CEZ & 0,76 & 1,00 & 0,64 & 0,28 & $-0,51$ & 0,84 & 0,92 & 0,33 & 0,64 & 0,90 \\
\hline ERSTE & 0,75 & 0,64 & 1,00 & 0,32 & $-0,21$ & 0,50 & 0,75 & 0,09 & 0,33 & 0,61 \\
\hline KB & 0,19 & 0,28 & 0,32 & 1,00 & 0,29 & 0,03 & 0,50 & 0,47 & 0,53 & 0,36 \\
\hline MORR & $-0,37$ & $-0,51$ & $-0,21$ & 0,29 & 1,00 & $-0,76$ & $-0,20$ & 0,41 & 0,20 & $-0,47$ \\
\hline ORCO & 0,75 & 0,84 & 0,50 & 0,03 & $-0,76$ & 1,00 & 0,67 & 0,05 & 0,36 & 0,81 \\
\hline PX & 0,79 & $\mathbf{0 , 9 2}$ & 0,75 & 0,50 & $-0,20$ & 0,67 & 1,00 & 0,55 & 0,78 & 0,89 \\
\hline TEL & 0,20 & 0,33 & $\mathbf{0 , 0 9}$ & 0,47 & 0,41 & 0,05 & 0,55 & 1,00 & 0,77 & 0,37 \\
\hline UNIP & 0,46 & 0,64 & 0,33 & 0,53 & 0,20 & 0,36 & 0,78 & 0,77 & 1,00 & 0,63 \\
\hline ZENT & 0,80 & $\mathbf{0 , 9 0}$ & 0,61 & 0,36 & $-0,47$ & 0,81 & $\mathbf{0 , 8 9}$ & 0,37 & 0,63 & 1,00 \\
\hline
\end{tabular}

Note: $\mathrm{KB}=$ Komercni banka, MORR $=$ Philip Morris, TEL $=$ Telefonica O2, UNIP $=$ Unipetrol, ZEN $=$ Zentiva.

Furthermore we tested first whether there is any cointegration among stocks at the PSE at all and then we used the results of the cointegration test for estimating the vector error correction models or VAR models on differences. In order to test cointegration we used the Johansen maximum likelihood approach described in the $2^{\text {nd }}$ section with various specifications of cointegrating relations based on Johansen (1995) and incorporated in EViews. According to the fact that not all stocks were traded during the whole period 2001-2006 we've decided to perform the analysis and estimates on subsamples - see Table 2 for detailed description. The reason was that in before mid 2004 (IPO of Zentiva) there had been really strong demand for a new stocks at the PSE for two years but no company wanted to be the first one, who would try to offer its stocks to the market and after Zentiva's successful IPO the others followed and until now every new IPO was very successful and the new stocks started to be traded in big volumes immediately and they became important part of the PX index. Thus omitting them could cause significant biases in the analysis. The side effect of the necessity of subsamples is that we can see how the interrelations among stocks changed in time and as it will be shown further the impact of robust growth and massive inflow of capital to the PSE. 
Table 2: Samples

\begin{tabular}{|l|c|c|c|l|}
\hline \multirow{2}{*}{ Sample } & \multicolumn{1}{|c|}{ Period } & \multicolumn{2}{|c|}{ No. of observations } & \multirow{2}{*}{ Stocks } \\
\cline { 2 - 4 } Main & $\begin{array}{c}\mathrm{M} / \mathrm{D} / \mathrm{Y}) \\
1 / 02 / 2001- \\
12 / 12 / 2006\end{array}$ & 1491 & 303 & $\begin{array}{l}\text { CEZ, KB, PHILIP MORRIS, PX, } \\
\text { TELEFONICA, UNIPETROL }\end{array}$ \\
\hline Four Years & $\begin{array}{l}10 / 10 / 2002- \\
12 / 12 / 2006\end{array}$ & 1050 & 212 & $\begin{array}{l}\text { CEZ, ERSTE, KB, PHILIP MORRIS, } \\
\text { PX, TELEFONICA, UNIPETROL }\end{array}$ \\
\hline Longer & $\begin{array}{l}3 / 01 / 2005- \\
12 / 12 / 2006\end{array}$ & 452 & 91 & $\begin{array}{l}\text { CEZ, ERSTE, KB, PHILIP MORRIS, } \\
\text { ORCO, PX, TELEFONICA, } \\
\text { UNIPETROL, ZENTIVA }\end{array}$ \\
\hline Bubble & $\begin{array}{l}3 / 01 / 2005- \\
9 / 12 / 2006\end{array}$ & 389 & 66 & $\begin{array}{l}\text { CEZ, ERSTE, KB, PHILIP MORRIS, } \\
\text { ORCO, PX, TELEFONICA, } \\
\text { UNIPETROL, ZENTIVA }\end{array}$ \\
\hline All & $\begin{array}{l}7 / 08 / 2005- \\
12 / 12 / 2006\end{array}$ & 362 & 71 & $\begin{array}{l}\text { CETV, CEZ, ERSTE, KB, PHILIP } \\
\text { MORRIS, ORCO, PX, TELEFONICA, } \\
\text { UNIPETROL, ZENTIVA }\end{array}$ \\
\hline
\end{tabular}

Specifications of all tested models is reported in tables 3 and 4 - the tables shows whether VECM or VAR on differences in case of no cointegration has been used, number of cointegrating vectors from Lambda max and Maximum Eigenvalue tests, number of cointegrating equations in the VECM and number of lags of variables included in the model. Concerning cointegration tests we took the 5\% significance level and the specification of the cointegrating relation was chosen according to Akaike and Schwartz information criteria, if they were not consistent, we used that one, which gave better results in subsequent VECM models. The significance level at 5\% seemed to be reasonable, because in case of the subsample „ALL" with daily data, the test implied one cointegrating vector at 0.1 level, but taking VECM instead of VAR specification did lead neither to better results in terms of reported R-squared in the equations nor in significance of the error correction terms in the VECM models.

Number of lags was set in order to obtain insignificant autocorrelations and cross autocorrelations in the model (see the Footnote 2 for a more detailed discussion). Several problems occurred with the models with daily data - sometimes the residuals were the "real" white noise with VAR(15) specifications, because several minor significant lags remained, however such models had too complicated structure and benefits for overall significance of that particular model were almost negligible. The goodness of fit remained nearly the same with 6 lags as with more so we decided not to include more in estimation.

Table 3: Model Specifications: Daily Data

\begin{tabular}{|l|c|c|c|c|}
\hline & Method & $\begin{array}{l}\text { Cointegrating vectors } \\
\text { (Lambda max/Max } \\
\text { eigenvalue) }\end{array}$ & $\begin{array}{l}\text { No. of cointegrating } \\
\text { equations in VECM }\end{array}$ & No. of lags \\
\hline Main & VECM & $2 / 1$ & 1 & 4 \\
\hline Four Years & VECM & $2 / 0$ & 2 & 6 \\
\hline Longer & VAR & $0 / 0$ & 0 & 6 \\
\hline Bubble & VAR & $0 / 0$ & 0 & 6 \\
\hline All & VAR & $0 / 0$ & 0 & 6 \\
\hline
\end{tabular}

Surprisingly the frequency of the data didn't have impact for the whole sample and also for the subsample called „Four Years“, but the differences in qualitative results for 
remaining samples were amazing. On one hand the cointegration tests using daily data did not indicate any cointegrating vector for the period 2005-2006, which would imply that all stocks move almost independently from each other, on the other using weekly data we found very strong ties between the stocks and we can see that all variables can be described with only 2 or 3 common stochastic trends.

Table 4: Model Specifications: Weekly Data

\begin{tabular}{|l|c|c|c|c|}
\hline & Method & $\begin{array}{l}\text { Cointegrating vectors } \\
\text { (Lambda max/Max } \\
\text { eigenvalue) }\end{array}$ & $\begin{array}{l}\text { No. of cointegrating } \\
\text { equations in VECM }\end{array}$ & No. of lags \\
\hline Main & VECM & $1 / 1$ & 1 & 4 \\
\hline Four Years & VECM & $2 / 0$ & 2 & 4 \\
\hline Longer & VECM & $9 / 6$ & 6 & 5 \\
\hline Bubble & VECM & $9 / 6$ & 6 & 4 \\
\hline All & VECM & $10 / 8$ & 8 & 4 \\
\hline
\end{tabular}

Quantitative results are reported partly in Table 4. Again the results for samples „Main“ and „Four Years“ are consistent and comparable, the difference between the values of R-squared at daily and weekly data can be explained by much higher level of noise in daily data. We can also see, that shorter period and presence of a new stock lead to slightly better results. Surprising are the results for the shorter period. Both three samples lead to completely different results with respect to the values of R-squared, partly due to the difference in specification of the model (VAR for daily data and VECM for weekly with either 6 or 8 cointegrating equations). Furthermore the values of the R-sq itself are great. The performance of the VECM model in comparison to VAR in differences can be seen in last two rows of the table - the difference is between 20 and $30 \%$ with one exception - Komercni banka - indicating that Komercni banka moved more independently than the other stocks. Such a strong effect is also a bit surprising as the theoretical explanations of cointegration among those stocks are not very rigorous and there can be found also a lot of arguments against it, at least because cointegration is really very strong relationship and, namely in a short term, stocks usually follow something very similar to random walk and trades are biased by so many animal spirits, cognitive biases or collective turn of minds, namely on emerging markets.

\section{Table 5: R-squared for each variable in estimated models}

\begin{tabular}{|l|l|c|c|c|c|c|c|c|c|c|c|}
\hline Sample & Freq. & CETV & CEZ & ERSTE & KB & MORR & ORCO & PX & TEL & UNIP & ZENT \\
\hline \multirow{2}{*}{ Main } & Daily & $\mathrm{xxx}$ & $15,0 \%$ & $\mathrm{xxx}$ & $3,4 \%$ & $1,6 \%$ & $\mathrm{xxx}$ & $1,4 \%$ & $1,5 \%$ & $3,2 \%$ & $\mathrm{xxx}$ \\
\cline { 2 - 12 } & Weekly & $\mathrm{xxx}$ & $16,2 \%$ & $\mathrm{xxx}$ & $10,9 \%$ & $8,1 \%$ & $\mathrm{xxx}$ & $11,5 \%$ & $13,1 \%$ & $13,4 \%$ & $\mathrm{xxx}$ \\
\hline \multirow{2}{*}{ Four Years } & Daily & $\mathrm{xxx}$ & $5,8 \%$ & $4,4 \%$ & $8,0 \%$ & $2,9 \%$ & $\mathrm{xxx}$ & $6,6 \%$ & $5,5 \%$ & $8,1 \%$ & $\mathrm{xxx}$ \\
\cline { 2 - 12 } & Weekly & $\mathrm{xxx}$ & $21,4 \%$ & $5,7 \%$ & $21,3 \%$ & $13,8 \%$ & $\mathrm{xxx}$ & $14,9 \%$ & $16,3 \%$ & $17,4 \%$ & $\mathrm{xxx}$ \\
\hline \multirow{2}{*}{ Longer } & Daily & $\mathrm{xxx}$ & $14,1 \%$ & $13,2 \%$ & $10,3 \%$ & $10,9 \%$ & $14,6 \%$ & $13,1 \%$ & $9,3 \%$ & $18,3 \%$ & $16,7 \%$ \\
\cline { 2 - 11 } & Weekly & $\mathrm{xxx}$ & $79,8 \%$ & $73,3 \%$ & $64,8 \%$ & $59,8 \%$ & $57,8 \%$ & $75,6 \%$ & $76,1 \%$ & $78,9 \%$ & $72,7 \%$ \\
\hline \multirow{2}{*}{ Bubble } & Daily & $\mathrm{xxx}$ & $15,9 \%$ & $15,2 \%$ & $13,7 \%$ & $12,9 \%$ & $17,1 \%$ & $15,3 \%$ & $11,4 \%$ & $19,3 \%$ & $20,7 \%$ \\
\cline { 2 - 11 } & Weekly & $\mathrm{xxx}$ & $87,0 \%$ & $69,0 \%$ & $69,1 \%$ & $80,2 \%$ & $66,7 \%$ & $80,5 \%$ & $80,3 \%$ & $85,4 \%$ & $85,2 \%$ \\
\hline \multirow{2}{*}{ All } & Daily & $15,4 \%$ & $18,2 \%$ & $15,9 \%$ & $15,9 \%$ & $16,6 \%$ & $18,0 \%$ & $18,0 \%$ & $15,2 \%$ & $19,8 \%$ & $24,0 \%$ \\
\cline { 2 - 11 } & Weekly & $81,7 \%$ & $89,2 \%$ & $80,0 \%$ & $66,2 \%$ & $57,5 \%$ & $78,5 \%$ & $82,6 \%$ & $73,4 \%$ & $87,3 \%$ & $80,6 \%$ \\
\hline \multirow{2}{*}{ All - VAR } & Weekly & $\mathbf{5 3 , 5 \%}$ & $\mathbf{6 7 , 3} \%$ & $\mathbf{5 6 , 1 \%}$ & $\mathbf{6 0 , 0} \%$ & $\mathbf{3 5 , 5 \%}$ & $\mathbf{4 9 , 1 \%}$ & $\mathbf{5 7 , 1 \%}$ & $\mathbf{5 2 , 0 \%}$ & $\mathbf{6 6 , 7 \%}$ & $\mathbf{6 1 , 3 \%}$ \\
\hline
\end{tabular}

As far as values and significance of estimated coefficients in the models concerns, models with high R-squared had usually the error correction terms significant (in the sense that a lot of them were significant) and they also usually had expected negative sign. As the significance of the error correction terms belonging to particular variables - 
that the change of CEZ returns would depend on the error correction terms from the cointegrating equations in which CEZ would be included - is natural and logical, the other significant terms indicate that the interrelations in the whole group are very complex and without any clear structure. Models with daily data: error correction terms were significant in case of the „Four Years“ sample, not so much in the sample „Main“. The signs were mixed.

\section{Daily-Weekly Puzzle}

How to explain such an important difference between the two groups of results? Why the choice of frequency has such important consequences? One hypothesis says that it can be caused by higher noise in daily data. This would mean that weekly data contains more or less long-term signal and the choice of weekly data can have similar consequences as using low-pass filter. In favor to the hypothesis that this effect is caused by high noise would be the excess volatility in returns, which can be seen as the most important violence of the assumptions of effective markets. Shiller (2003) argues that excess volatility is more important than various anomalies and cognitive limitations studied by the behavioral economists because it implies that stock prices movements reflect various animal spirits and changes from optimistic to pessimistic perception of the situation much more than changes in fundamental factors. Generally emerging markets have higher volatility also due to structure of investors, who are actively participating on the market, as conservative institutions like pension founds play only minor role here and the other investors are not so risk-averse.

The other possible cause of different results for daily and weekly data may be that prices of stocks do not reflect the changes in fundamental factors perfectly. Usually agents use technical analysis as underlying information for trading and fundamental factors are guide for long-term trades.

Some bias can be also caused by low number of observations in weekly data, which is for the subsamples 2005/2006 lower then 100. Nevertheless other tools - like correlation coefficients and Granger causality based on previous results lead to consistent results between daily and weekly data.

\section{Conclusion}

The main purpose of this text was to analyze the interrelationships among stocks at the Prague Stock Exchange in recent years using cointegration and vector errorcorrection models. We found that the results of both, presence of cointegration and estimates of VECM (VAR) models differ substantially for the years of the highest growth rates of the PX index on data frequencies (daily or weekly), whereas the results are consistent for the whole sample 2001-2006. For the whole sample both frequencies indicate one or two cointegrating vectors and particular VECM models explain on average $5 \%$ of variance using daily data and $15 \%$ using weekly respectively. However for the subsamples in 2005/2006 daily data indicated no cointegration but on contrary weekly data implied strong cointegration with 6 or 8 cointegration vectors. Also explained variance using VAR or VECM models differs substantially as it touch the level of $15-17 \%$ with daily data and $70-80 \%$ and more using weekly data. 
Such difference has not been explained satisfactory - our hypothesis is that it can be caused either by higher noise in daily data, or just by the effect of different approach of agents on the financial markets who use technical analysis for daily trades and analysis of fundamentals for long-term investments.

The implications of our finding support our hypotheses that the growth was common to all stocks on the market and that it has been driven by common factors like optimistic perception of the whole region of the Central and Eastern Europe by the community of investors based on undervalued stocks, high growth of the economies and also of the profits as well. As the financial data are generally optimistic for all companies (in our sample) and as the perceptions of their perspectives is positive as well, those factors play currently for those companies more important role than the differences in sectors.

\section{Acknowledgement}

The author would like to thank Miloslav S. Vošvrda, Jozef Baruník and two anonymous reviewers for helpful comments. The usual disclaimer applies.

\section{References}

[1] EGERT, B.; KOČENDA, E. (2005). Contagion Across and Integration of Central and Eastern European Stock Markets: Evidence from Intraday Data. William Davidson Institute Working Paper, November 2005, no. 798.

[2] ENDERS, W. (2003). Applied Econometric Time Series. New York : John Wiley, 2003.

[3] FAMA, E. (1970). Efficient Capital Markets: A Review of Theory and Empirical Work. Journal of Finance, 1970, vol. 25, no. 2, pp.383-417.

[4] GRANGER, C. (1986). Developments in the Study of Cointegrated Economic Variables. Oxford Bulletin of Economics and Statistics, 1986, vol. 48, no. 3, pp. 213-228.

[5] HAMILTON, J. (1994). Time Series Analysis. Princeton : Princeton University Press, 1994.

[6] JOHANSEN, S. (1995). Likelihood-based Inference in Cointegrated Vector Autoregressive Models. Oxford : Oxford University Press, 1995.

[7] LÜTKEPOHL, H. (1991). Introduction to Multiple Time Series Analysis. New York : Springer Verlag, 1991.

[8] MOOSA, I. (1999). On the inconsistency between cointegration and crosssectional efficiency. Atlantic Economic Journal, 1999, vol. 27, no. 2, p. 233.

[9] SYLLIGNAKIS, M.; KOURETAS, G. (2006). Long and Short-Run Linkages in CEE Stock Markets: Implications for Portfolio Diversification and Stock Market Integration. William Davidson Institute Working Paper, November 2006, no. 832.

[10] ŽIKEŠS, F. (2004). Cross-Country Predictability and Cointegration: The Case of Central-European Stock Markets. In Blaha, Z. (ed.): Risk Management and Financial Engineering. Praha, Management Press, 2004, pp.137-149. 


\title{
Optimismus na akciovém trhu a kointegrace mezi akciemi: Př́pad BCP Praha
}

\author{
Jaromír Baxa
}

\begin{abstract}
Abstrakt
V uplynulých pěti letech zaznamenala pražská burza cenných papírů významný nárůst jak v objemech obchodování, tak v cenách akcií, její index PX (dř́ive PX-50) v letech 2001-2006 vzrostl téměř čtyřnásobně. Aplikace kointegrační analýzy umožňuje ukázat, jestli byl tento růst způsoben společnými faktory typu optimistického vnímání celého trhu nebo společnými fundamentálními faktory, a nebo jestli byl podobný nárůst dílem náhody. Zjistili jsme, že se výsledky dost liší v závislosti na volbě frekvence dat. Zatímco denní data ukazují na velmi slabé vazby mezi jednotlivými tituly, týdenní ukazují opak. Podobně denní data naznačují, že společná vazba je delší spíše v dlouhém období a prakticky se neobjevuje v období největšího růstu v letech 2005-2006, naproti tomu s týdenními daty byla silná kointegrace identifikovaná hlavně v kratším období. Výsledky odhadů VECM a VAR modelů byly překvapivě dobré - v týdenních datech se podařilo vysvětlit až 80 \% variance, v denních $20 \%$. Tento rozdíl může být způsoben bud' velkým šumem v denních datech nebo zvýšenou volatilitou na rozvíjejících se trzích.
\end{abstract}

Klíčová slova: trh akcií; optimismus; kointegrace.

\section{Stock Market Optimism and Cointegration among Stocks: The Case of the Prague Stock Exchange}

\begin{abstract}
The PSE noted incredible increase in both trading volumes and prices of traded stocks during last five years. The PX index (former PX-50) reached the level of 1600 points at the end of 2006, which is almost four times higher than in 2001. Cointegration analysis can show us if the growth has been driven by some hidden common factor(-s), either optimistic perception of the market or common fundamentals, or if the main forces have been in case of each stock individual and specific and the fact, that the increase was similar among many of stocks is only due to coincidence. We have found that the results differ substantially upon the choice of frequencies of the data. The interrelations are very small when using daily data, on the other hand weekly data lead to opposite result. Furthermore the analysis of daily data implies that the relations became closer in the long term and that they are almost negligible during the period of high growth (2005-2006), but again the weekly data showed the opposite. As far as results of the VECM and VAR estimates concern, they were surprisingly good: using weekly data we were able to explain up to $80 \%$ of variance in stock returns comparing to $20 \%$ with daily data. This difference can be explained partly as a consequence of high noise in daily data and excessive volatility on emerging markets.
\end{abstract}

Key words: stock market; optimism; cointegration.

JEL classification: C32, G19. 